\title{
Genetic diversity of Saudi native chicken breeds segregating for naked neck and frizzle genes using microsatellite markers
}

\author{
Moataz Fathi ${ }^{1,2, *}$, Mohamed El-Zarei ${ }^{1,3}$, Ibrahim Al-Homidan ${ }^{1}$, and Osama Abou-Emera ${ }^{1,4}$
}

* Corresponding Author: Moataz Fathi Tel: +966-594067644, Fax: +966-163801360,

E-mail: mmfathi@fulbrightmail.org

${ }^{1}$ Department of Animal Production and Breeding, College of Agriculture and Veterinary Medicine, Qassim University, Al-Qassim 51452, Saudi Arabia 2 Department of Poultry Production, Faculty of Agriculture, Ain Shams University, Hadayek Shoubra 11241, Cairo, Egypt

${ }^{3}$ Department of Animal Production, Faculty of Agriculture, Suez Canal University 41522, Ismailia, Egypt

${ }^{4}$ Department of Poultry Breeding, Animal Production Research Institute, Agriculture Research Center, Dokki, Giza 12618, Egypt

ORCID

Moataz Fathi

https://orcid.org/0000-0001-9207-3861

Submitted Jan 10, 2018; Revised Apr 15, 2018; Accepted May 7, 2018
Objective: Recently, there has been an increasing interest in conservation of native genetic resources of chicken on a worldwide basis. Most of the native chicken breeds are threatened by extinction or crossing with ecotypes.

Methods: Six Saudi native chicken breeds including black naked neck, brown frizzled, black, black barred, brown and gray were used in the current study. The aim of the current study was to evaluate genetic diversity, relationship and population structure of Saudi native chicken breeds based on 20 microsatellite markers.

Results: A total of 172 alleles were detected in Saudi native chicken breeds across all 20 microsatellite loci. The mean number of alleles per breed ranged from 4.35 in gray breed to 5.45 in normally feathered black with an average of 8.6 alleles. All breeds were characterized by a high degree of genetic diversity, with the lowest heterozygosity found in the brown breed (72\%) and the greatest in the frizzled and black barred populations (78\%). Higher estimate of expected heterozygosity (0.68) was found in both black breeds (normal and naked neck) compared to the other chicken populations. All studied breeds showed no inbreeding within breed (negative inbreeding coefficient $\left[\mathrm{F}_{\mathrm{IS}}\right]$ ). The phylogenetic relationships of chickens were examined using neighbor-joining trees constructed at the level of breeds and individual samples. The neighbor-joining tree constructed at breed level revealed three main clusters, with naked neck and gray breeds in one cluster, and brown and frizzled in the second cluster leaving black barred in a separate one.

Conclusion: It could be concluded that the genetic information derived from the current study can be used as a guide for genetic improvement and conservation in further breeding programs. Our findings indicate that the Saudi native chicken populations have a rich genetic diversity and show a high polymorphism.

Keywords: Genetic Diversity; Microsatellites; Saudi Native Chicken

\section{INTRODUCTION}

The importance of keeping genetic diversity in animals and poultry is supported worldwide by the Food and Agriculture Organization [1]. Most of native chicken are threatened by extinction or crossing with ecotypes. However, there has been a greater attention in recent years to the loss of biodiversity and extinction of poultry breeds [2]. It is well known that native chickens have socio-cultural and economic importance in the livelihoods of rural sector and households. There are many native chicken breeds segregating for major genes in Arabian Peninsula that are adapted for high environmental temperature and unfavorable conditions. Saudi consumers prefer native chickens and their products for meat and eggs. Moreover, as a consequence of natural selection, indigenous breeds have shown to possess superior disease resistance [3,4]. Fanciers believe that the naked neck and frizzle genes were brought into Saudi Arabia from European ecotype chicken strains in the ninth century. 
It can be assumed that indigenous breeds contain genes and alleles relevant to their adaptation to particular environmental circumstances and specific breeding strategies $[5,6]$. Using microsatellite markers as a tool for genetic diversity analysis among chicken breeds are well established [7-10]. It is an effective method to assess genetic diversity within and between chicken populations because they are highly polymorphic, show co-dominant inheritance, found to be abundant and evenly distributed throughout the genome [11-14]. Recently, few studies of genetic polymorphism were initiated on Saudi native chicken populations using mtDNA $[15,16]$ or microsatellite markers [4]. Due to the limited mtDNA diversity, it is necessary to analyze autosomal markers in Saudi native breeds, in order to study diversity and the relationship between breeds.

To our knowledge, Saudi native breeds segregating for major genes such as naked neck and frizzle genes were not included in any study. Therefore, the current study aimed at investigating the genetic diversity, relationship and population structure of Saudi native chicken carrying naked neck and frizzle genes based on 20 microsatellite markers.

\section{MATERIALS AND METHODS}

\section{Native chicken populations}

A total of 2,700 one-day old Saudi native chicks, representing six breeds (naked neck black, frizzled brown, black, black barred, brown and gray) (450 each) were kept in the poultry research station, Qassim University. The present breeds were collected and propagated under an extensive breeding program to purify and conserve native genetic recourses. All breeds were kept under similar management and environmental conditions. The care and handling of chickens were in accordance with regulations of animal care and ethics committee of Qassim University. The name, abbreviation, morphological appearance and photo for each population are summarized in Table 1. Also, geographical location of Saudi native chicken populations is shown in Figure 1.

\section{DNA extraction and microsatellite genotyping}

A total of 144 blood samples were collected from the different chicken populations (24 each). Approximately one $\mathrm{mL}$ blood/ bird from a wing vein was collected in ethylenediamine tetraacetic acid (EDTA) tubes and stored at $-20^{\circ} \mathrm{C}$. DNA was extracted from $0.5 \mathrm{~mL}$ of whole EDTA blood using ILLUSTRA blood mini spin kit (GE Life Sciences, Buckinghamshire, UK). Then, DNA samples were taken to determine the quantity and quality of DNA using Thermo Scientific Nano Drop 8000 UVVis Spectrophotometers. The selected microsatellites were amplified using ProFlex PCR System Applied Biosystems (Toronto, ON, Canada). The polymerase chain reaction (PCR) was performed for each locus in $10 \mu \mathrm{L}$ reactions consisted of $2 \mu \mathrm{L}$ of Genomic DNA (20 ng), $5 \mu \mathrm{L} 2 \times$ PCR AmpliTag gold
PCR Master mix (Applied Biosystems, Foster City, CA, USA), $0.4 \mu \mathrm{L}$ primer mix (50 pmoles) and 2.6 $\mu \mathrm{L}$ DNase free water. The PCR program was carried out at $95^{\circ} \mathrm{C}$ for $5 \mathrm{~min}$, followed by $30 \mathrm{cycles}$ of $95^{\circ} \mathrm{C}$ for $30 \mathrm{~s}$. Annealing temperature (ranged from $58^{\circ} \mathrm{C}$ up to $64^{\circ} \mathrm{C}$ depending on primers sequence) was determined for each primer for $30 \mathrm{~s}$. and $72^{\circ} \mathrm{C}$ for $30 \mathrm{~s}$, and final extension at $72^{\circ} \mathrm{C}$ for $10 \mathrm{~min}$. Following the completion of the PCR cycles, $3 \mu \mathrm{Lof}$ the reaction products was mixed with $1 \mu \mathrm{L} 6 \times$ gel loading dye and then loaded into each well of vertical $8 \%$ polyacrylamide gel made with $1 \times$ tris base, boric acid and EDTA buffer at $100 \mathrm{~V}$ for 60 to $90 \mathrm{~min}$ and stained

Table 1. Description of morphological appearance of the Saudi native chicken populations

\begin{tabular}{|c|c|c|}
\hline Breed & Abbreviation & $\begin{array}{c}\text { Morphological } \\
\text { appearance/description }\end{array}$ \\
\hline $\begin{array}{l}\text { Normally } \\
\text { feathered } \\
\text { black }\end{array}$ & BL-nana & $\begin{array}{l}\text { The predominant plumage } \\
\text { color for males and } \\
\text { females is a solid shiny } \\
\text { black. Both sexes are } \\
\text { entirely black as adults; } \\
\text { name derived from plum- } \\
\text { age color appearance. }\end{array}$ \\
\hline
\end{tabular}

$\begin{array}{ll}\begin{array}{c}\text { Black } \\ \text { barred }\end{array} & \text { The predominant plumage } \\ \text { color for both sexes is } \\ \text { black with white stripes. } \\ \text { The name is derived from } \\ \text { plumage pattern. }\end{array}$

\begin{tabular}{|c|c|c|}
\hline $\begin{array}{l}\text { Normally } \\
\text { feathered } \\
\text { brown }\end{array}$ & BR-ff & $\begin{array}{l}\text { Plumage color ranges from } \\
\text { light to dark brown, some- } \\
\text { times with black feathers } \\
\text { on the tail. Sometimes } \\
\text { feather's face is outwards. }\end{array}$ \\
\hline Gray & $G$ & $\begin{array}{l}\text { Gray feathers are pre- } \\
\text { dominate. Crested head is } \\
\text { more frequent than in the } \\
\text { other breeds. }\end{array}$ \\
\hline
\end{tabular}
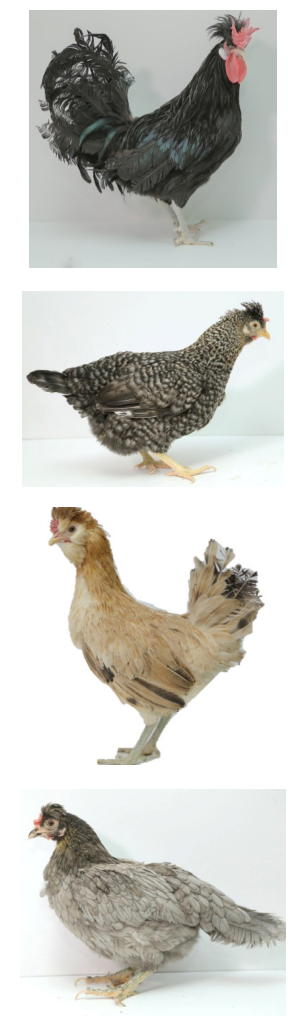

Heterozy- BL-Nana
gous
naked
neck black

Multi-colored feather coat

Heterozy- BR-Ff The predominant plumage gous frizzled brown with various plumage patterns. Black color is more frequent with medium sized and ornamental appearance. Found in hot middle and southern regions of KSA

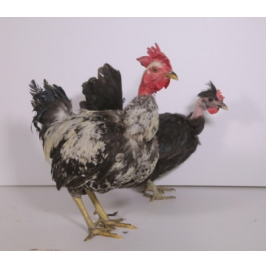

color for both sexes is dark brown with black feathers in abdomen and tail. Carrying various comb types. Found in a village of central region Al-Qassim province, KSA

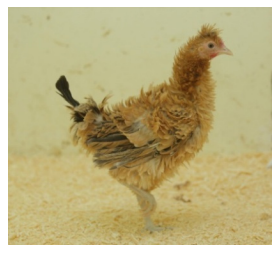




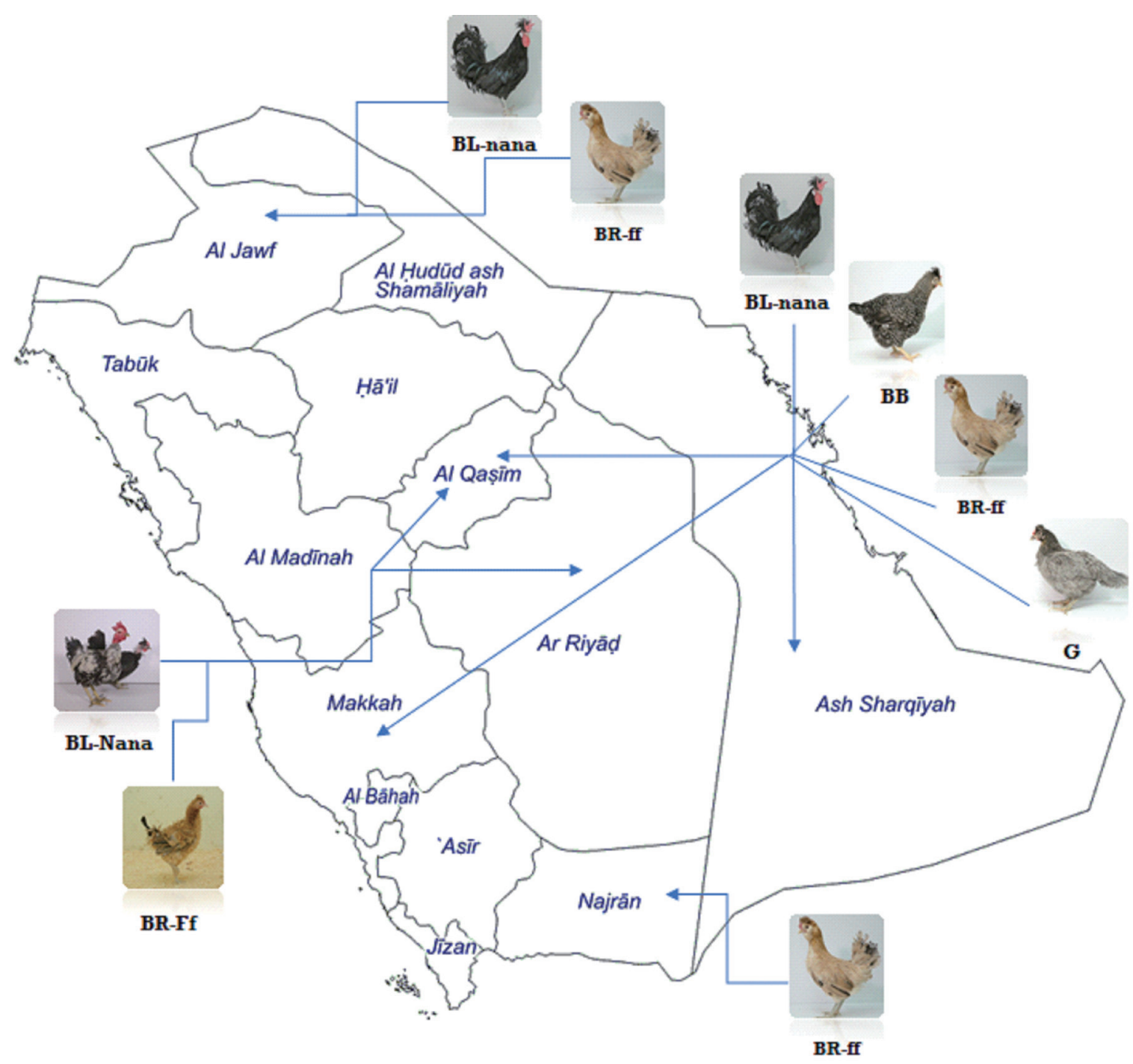

Figure 1. Geographical location of Saudi native chicken populations.

with Ethidium bromide (1\%). A 50 bp DNA ladder was used to estimate allele sizes in base pairs (bp). A reference bird was used to compare and correct allelic size in each gel. Twenty microsatellite markers distributed on 14 autosomal chromosomes and previously used by Fathi et al [4] and recommended by the International Society of Animal Genetics (ISAG)-FAO [1] were selected to assess the genetic diversity among Saudi native chicken breeds (Table 2).

\section{Data analysis}

Genetic variability was estimated per locus and across all loci for each population by allelic frequencies, observed heterozygosity, expected heterozygosity in all populations (as estimated from the pooled allele frequencies $\left[\mathrm{H}_{\mathrm{T}}\right]$ ), expected heterozygosity estimated within a population $\left(\mathrm{H}_{\mathrm{S}}\right)$ and Hardy Weinberg equilibrium (HWE) using GENETIX program [17] and GENEPOP 4.1 software [18].
The $\mathrm{F}_{\mathrm{IT}}$ (inbreeding coefficient of an individual relative to the total population), $\mathrm{F}_{\mathrm{ST}}$ (the effect of subpopulations compared with the total populations), and $\mathrm{F}_{\mathrm{IS}}$ (inbreeding coefficient of an individual relative to the subpopulation) and values for each breed were calculated using the FSTAT 2.9.3 [19] and GENEPOP 4.1 software [18]. The following formulas were used to calculate their values:

$$
\begin{aligned}
& \mathrm{F}_{\text {IT }}=1-\frac{H I}{H T} \\
& \mathrm{~F}_{\mathrm{IS}}=1-\frac{H I}{H S} \\
& \mathrm{~F}_{\mathrm{ST}}=1-\frac{H S}{H T}
\end{aligned}
$$

Where, HT, total gene diversity or expected heterozygosity in the total population as estimated from the pooled allele frequencies; HI, intra-population gene diversity or average 
Table 2. Description of 20 microsatellite markers used in the current study

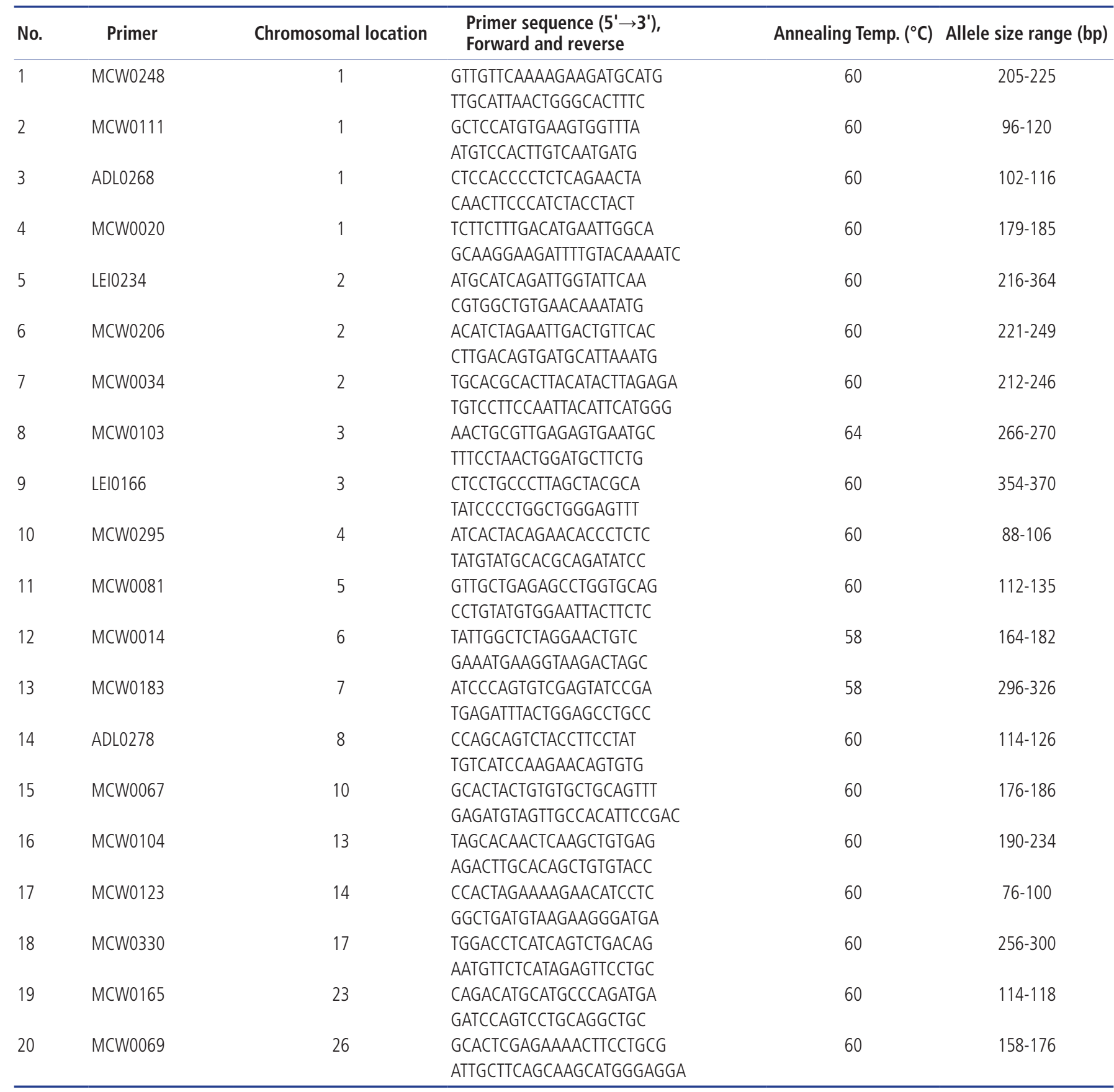

observed heterozygosity in a group of populations; HS, average expected heterozygosity estimated from each subpopulation.

Genetic distance was computed between populations without a bias correction [20]. These genetic distances were developed based on different models of molecular evolution and/or different taxonomic units [21]. The POPTREE2 program V. 2.0 [22] was used to perform evolutionary analyses of allele frequency data to construct a phylogenetic tree for the studied breeds. A neighbor-joining (NJ) tree of the seven chicken populations was constructed.

\section{RESULTS AND DISCUSSION}

\section{Ploymorphism of markers}

Across the 20 microsatellite markers studied, a total of 172 alleles were identified in all native chicken breeds (Table 3). All studied loci were polymorphic in all chicken breeds. Overall, the lowest number of alleles per locus ( 5 alleles) was recorded for MCW0034 and MCW00165, while the highest number (15 alleles) was recorded for LEI0234. The average number of alleles per locus was 8.6. The highest mean number of alleles was recorded in the black breed (5.5), whereas, the lowest 
Table 3. Number of alleles per locus per chicken breed

\begin{tabular}{|c|c|c|c|c|c|c|c|}
\hline \multirow{2}{*}{ Locus } & \multicolumn{6}{|c|}{ Breed } & \multirow{2}{*}{ Overall } \\
\hline & BL-Nana & BR-Ff & BL-nana & BR-ff & BB & G & \\
\hline MCW0020 & 3 & 6 & 6 & 4 & 3 & 3 & 8 \\
\hline LEI0166 & 6 & 6 & 6 & 5 & 6 & 4 & 8 \\
\hline MCW0111 & 4 & 4 & 5 & 4 & 5 & 5 & 7 \\
\hline MCW0034 & 4 & 3 & 3 & 4 & 3 & 4 & 5 \\
\hline MCW0067 & 3 & 6 & 5 & 4 & 4 & 6 & 8 \\
\hline MCW0165 & 7 & 5 & 7 & 7 & 8 & 5 & 12 \\
\hline MCW0020 & 4 & 4 & 4 & 5 & 5 & 3 & 8 \\
\hline MCW0103 & 6 & 4 & 5 & 5 & 5 & 4 & 8 \\
\hline MCW0165 & 4 & 5 & 5 & 4 & 4 & 3 & 5 \\
\hline MCW0104 & 8 & 6 & 8 & 7 & 8 & 7 & 13 \\
\hline MCW0069 & 6 & 6 & 7 & 4 & 4 & 4 & 8 \\
\hline MCW0014 & 5 & 4 & 6 & 5 & 6 & 4 & 7 \\
\hline ADL0278 & 6 & 5 & 7 & 6 & 5 & 3 & 10 \\
\hline MCW0248 & 6 & 5 & 6 & 6 & 8 & 6 & 9 \\
\hline LEI0234 & 9 & 5 & 7 & 7 & 7 & 5 & 15 \\
\hline MCW0123 & 3 & 5 & 5 & 3 & 3 & 2 & 10 \\
\hline MCW0081 & 6 & 5 & 3 & 3 & 4 & 4 & 6 \\
\hline MCW0183 & 6 & 5 & 5 & 6 & 6 & 5 & 9 \\
\hline MCW0295 & 5 & 6 & 4 & 4 & 4 & 5 & 7 \\
\hline ADL0268 & 3 & 5 & 5 & 5 & 5 & 5 & 9 \\
\hline Average & $5.2 \pm 0.38$ & $5.0 \pm 0.19$ & $5.5 \pm 0.30$ & $4.9 \pm 0.28$ & $5.2 \pm 0.37$ & $4.4 \pm 0.27$ & $8.6 \pm 0.56$ \\
\hline
\end{tabular}

BL-Nana, heterozygous naked neck black; BR-Ff, heterozygous frizzled brown; BL-nana, normally feathered black; BR-ff, normally feathered brown; BB, black barred; G, gray. Mean \pm standard error.

number (4.4) was recorded in gray breed. However, FAO has specified a minimum of 4 distinct alleles per locus for efficient judgment of genetic diversity between breeds. Generally, both black chicken genotypes (naked neck and normally feathered) exhibit a high genetic diversity in terms of number of alleles. This may be due to the fact that the black chickens are more popular and are distributed in a wide area. The lowest allelic diversity observed in gray breed may also suggest a high degree of inbreeding. The mean number of alleles of Saudi native populations was higher than that of Taiwanese conserved breeds [23] and Vietnamese domestic chicken populations [24]. Compared with our findings (8.6 alleles), Shahbazi et al [25] reported a mean number of alleles of 4.8 per locus in Iranian native chickens. While, Kaya and Yildiz [26] reported that the mean number of alleles among studied loci for Turkish native chickens was 7.5. These values were lower than those reported by Zhang et al [7], who stated that there were 9.3 alleles in Chinese native chicken breeds. However, the number of alleles at a single microsatellite locus in any single chicken population has ranged from one (monomorphic) up to several $[27,28]$. The average of alleles per locus observed ranged from 3.4 to 9.3 in non-commercial birds $[25,26,29,30]$. The higher values of alleles in non-commercial chickens in relation to the commercials are due to a strong pressure of artificial selection which occurred in the latter.

\section{Fixation indices and heterozygozity}

Fixation indices $\left(\mathrm{F}_{\mathrm{IT}}, \mathrm{F}_{\mathrm{ST}}\right.$, and $\left.\mathrm{F}_{\mathrm{IS}}\right)$ estimated according to Weir and Cockerham [31] are listed in Table 4. Also, the estimates of observed heterozygosity $\left(\mathrm{H}_{\mathrm{O}}\right)$ and expected heterozygosity $\left(\mathrm{H}_{\mathrm{E}}\right)$ were recorded based on allele frequency data for each locus per breed (Table 4 ). The average of observed heterozygozity was quite high $(0.76)$ with a range of 0.35 to 0.91 . The MCW0123 marker recorded the lowest figure (0.35), while the MCW0183 marker recorded the highest one (0.91). Expected heterozygosity recorded an average of 0.71 across all loci, ranging from 0.44 (MCW0123) to 0.83 (MCW0165). Similar average was found $(0.71)$ for total gene diversity $\left(\mathrm{H}_{\mathrm{T}}\right)$ across all native chicken breeds. However, the mean of $\mathrm{H}_{\mathrm{E}}$ recorded in the current study was lower than that reported by Zhang et al [7] in Chinese native chickens. On the other hand, $\mathrm{H}_{\mathrm{E}}$ was higher than that of Hillel et al [32], who reported that the average gene diversity within 52 breeds across all 22 loci was 0.47 . The variation of expected heterozygosity may be due to the differences in location, sample size, breed structure and microsatellite markers [33]. The highest value of total gene diversity $\left(\mathrm{H}_{\mathrm{T}}\right)$ for all studied breeds was 0.85 (MCW016), which meant that this locus was a highly informative locus among all loci. On the other hand, the value of $\mathrm{H}_{\mathrm{T}}$ for MCW012 was 0.48 , indicating a slightly informative locus.

The $\mathrm{F}_{\text {IS }}$ represents a degree of nonrandom mating (deviation from $\mathrm{HWE}$ ). A positive number for $\mathrm{F}_{\mathrm{IS}}$ means deviation from 
Table 4. Fixation indices $\left(F_{T,} F_{S T}\right.$ and $\left.F_{1 S}\right)$ and observed $\left(H_{0}\right)$ and expected $\left(H_{E}\right)$ heterozygosities per locus across six Saudi native chicken breeds

\begin{tabular}{|c|c|c|c|c|c|c|}
\hline Locus & $F_{I T}$ & $\mathrm{~F}_{\mathrm{ST}}$ & $\mathrm{F}_{\mathrm{IS}}$ & $\mathrm{H}_{0}$ & $\mathrm{H}_{\mathrm{E}}$ & $\mathrm{H}_{\mathrm{T}}$ \\
\hline MCW0020 & 0.00 & 0.04 & -0.04 & 0.67 & 0.65 & 0.67 \\
\hline LEI0166 & -0.09 & 0.03 & -0.11 & 0.90 & 0.80 & 0.82 \\
\hline MCW0034 & -0.19 & 0.03 & -0.22 & 0.78 & 0.64 & 0.64 \\
\hline MCW0067 & 0.06 & 0.01 & 0.05 & 0.66 & 0.71 & 0.71 \\
\hline MCW0165 & 0.03 & 0.02 & 0.01 & 0.80 & 0.83 & 0.85 \\
\hline MCW0165 & 0.01 & 0.04 & -0.03 & 0.67 & 0.64 & 0.65 \\
\hline MCW0104 & 0.04 & 0.01 & 0.02 & 0.79 & 0.81 & 0.82 \\
\hline MCW0069 & -0.12 & -0.02 & -0.11 & 0.71 & 0.66 & 0.65 \\
\hline MCW0014 & -0.05 & 0.00 & -0.05 & 0.83 & 0.77 & 0.77 \\
\hline ADL0278 & -0.09 & 0.00 & -0.09 & 0.71 & 0.65 & 0.66 \\
\hline MCW0081 & -0.23 & 0.02 & -0.25 & 0.88 & 0.70 & 0.71 \\
\hline MCW0183 & -0.14 & 0.04 & -0.18 & 0.91 & 0.77 & 0.79 \\
\hline MCW0295 & 0.01 & -0.01 & 0.03 & 0.74 & 0.75 & 0.74 \\
\hline ADL0268 & -0.15 & -0.01 & -0.14 & 0.79 & 0.68 & 0.68 \\
\hline Overall & -0.06 & 0.02 & -0.08 & 0.76 & 0.71 & 0.71 \\
\hline
\end{tabular}

$F_{T, T}$ inbreeding coefficient of an individual relative to the total population; $F_{S T,}$ the effect of subpopulations compared with the total populations; $F_{I S,}$ inbreeding coefficient of an individual relative to the subpopulation; $H_{E}$, average expected heterozygosity estimated from each population; $H_{T,}$ total gene diversity or expected heterozygosity in the total population as estimated from the pooled allele frequencies.

HWE. Only MCW0069, MCW0165, MCW0103, MCW0123, and MCW0295 showed a positive number. Out of all used markers, $75 \%$ showed negative figures. Relatively, low average $\mathrm{F}_{\mathrm{IS}}(-0.08)$ across all loci in the resent study was recorded, indicating non-random mating in the Saudi native chicken breeds. However, $\mathrm{F}_{\text {IS }}$ is used to obtain a deeper insight in appraising the degree of in-breeding and endangerment potentiality and is considered as an important tool to judge the conservation priority [34]. Accordingly, when $\mathrm{F}_{\mathrm{IS}}$ is less than 0.05 , the breeds are not in danger. On average, the genetic differentiation index, $\mathrm{F}_{\mathrm{ST}}$, among breeds was 0.02 (Table 4). About $2 \%$ of the total genetic variation corresponded to the differences between breeds and the remaining $98 \%$ was the result of variation among individuals within breed. Ramadan et al [34] found a $8 \%$ of genetic differentiation across 21 studied loci used among six Egyptian local strains. A higher estimated value of $\mathrm{F}_{\mathrm{ST}}(0.357)$ owing to line differences was recorded in pure-bred commercial chicken [35].

The expected heterozygosity was lower than the observed heterozygosity for all chicken breeds (Table 5). All populations were characterized by a high degree of genetic diversity, with the lowest heterozygosity found in the brown breed (72\%) and the greatest in the frizzled and black barred populations (78\%). Higher estimates of expected heterozygosity $(0.68)$ were found in both black breeds (normal and naked neck) compared to the other chicken populations. Moreover, the normally fea-

Table 5. Genetic variability estimates for 20 microsatellite loci in six native chicken populations

\begin{tabular}{|c|c|c|c|c|c|c|c|}
\hline \multirow{2}{*}{ Breed } & \multicolumn{3}{|c|}{ Fixation indices } & \multirow{2}{*}{ Alleles/locus } & \multicolumn{2}{|c|}{ Heterozygosity } & \multirow{2}{*}{ dHWE } \\
\hline & $F_{1 S}$ & $\mathrm{~F}_{\mathrm{IT}}$ & $\mathrm{F}_{\mathrm{ST}}$ & & $\mathrm{H}_{0}$ & $\mathrm{H}_{\mathrm{E}}$ & \\
\hline BL-Nana & -0.01 & -0.07 & 0.02 & $5.20 \pm 1.70$ & $0.72 \pm 0.15$ & $0.68 \pm 0.12$ & 2 \\
\hline BR-Ff & -0.09 & -0.05 & 0.02 & $5.00 \pm 0.86$ & $0.78 \pm 0.12$ & $0.67 \pm 0.07$ & 0 \\
\hline BL-nana & -0.08 & -0.05 & 0.02 & $5.45 \pm 1.36$ & $0.77 \pm 0.14$ & $0.68 \pm 0.09$ & 1 \\
\hline BR-ff & -0.10 & -0.07 & 0.01 & $4.90 \pm 1.25$ & $0.72 \pm 0.18$ & $0.62 \pm 0.13$ & 1 \\
\hline BB & -0.10 & -0.05 & 0.02 & $5.15 \pm 1.63$ & $0.78 \pm 0.16$ & $0.67 \pm 0.13$ & 0 \\
\hline G & -0.05 & -0.06 & 0.02 & $4.35 \pm 1.23$ & $0.77 \pm 0.27$ & $0.67 \pm 0.14$ & 0 \\
\hline
\end{tabular}

BL-Nana, heterozygous naked neck black; BR-Ff, heterozygous frizzled brown; BL-nana, normally feathered black; BR-ff, normally feathered brown; BB, black barred; G, gray; $\mathrm{H}_{0}$ observed heterozygosity; $\mathrm{H}_{\mathrm{E}}$ expected heterozygosity; dHWE, number of loci deviating from Hardy-Weinberg equilibrium after Bonferroni correction.

Mean \pm standard deviation. 


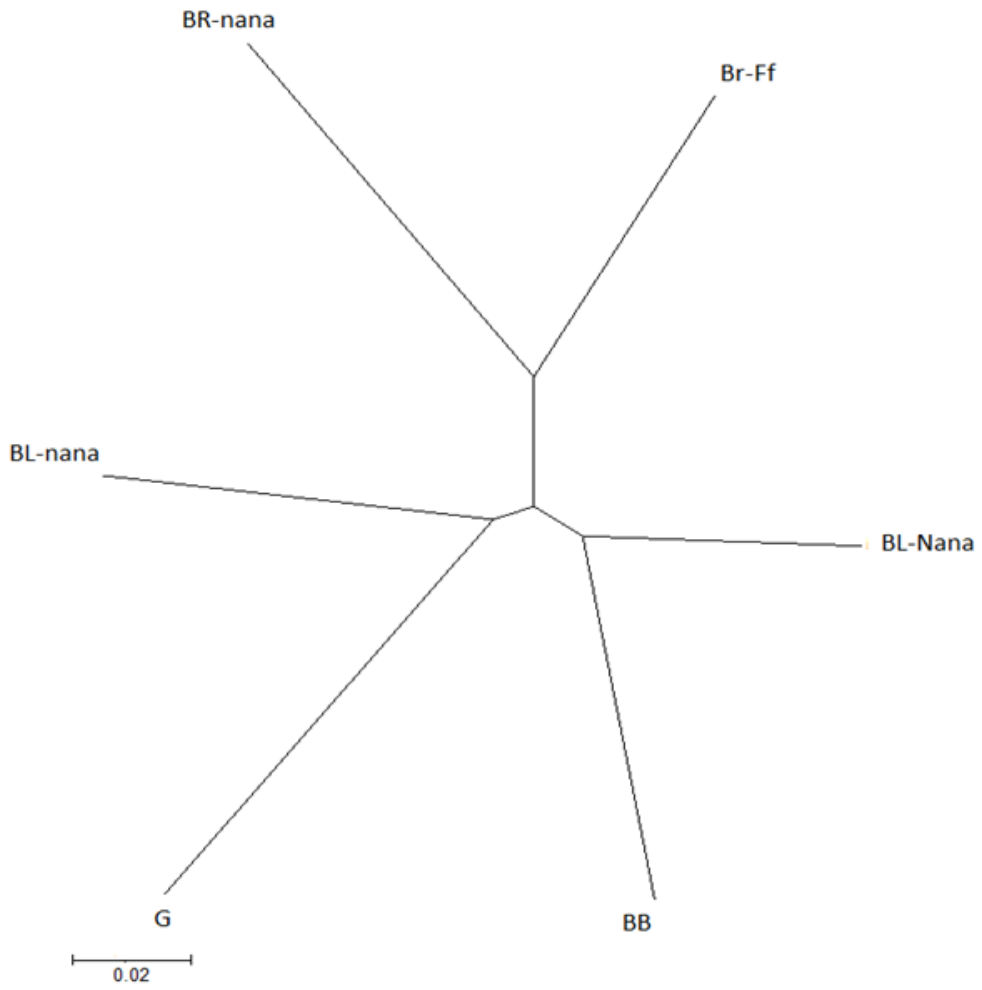

Figure 2. Unrooted neighbor-joining tree constructed using Nei's genetic distance of Saudi native chicken breeds.

thered brown breed recorded the lowest expected heterozygosity (0.62). In comparison with naked neck and frizzled chickens kept mainly by fanciers, normally feathered Saudi native chickens exhibited a lower degree of heterozygosity. However, native chickens carrying major genes are kept by fanciers as ornamental breeds in small size populations in many regions of central and south area of Saudi Arabia. This condition seems to result in a higher degree of diversity than the other breeds. Normally feathered black breed had the highest genetic variability in terms of expected heterozygosity (0.68) and number of alleles (5.45). This may be due to the fact that the black native chickens has been found in large number and distributed in a wide area of Saudi Arabia. BB and BR-Ff breeds recorded the highest difference between observed and expected heterozygosity. The $\mathrm{H}_{\mathrm{O}}$ and $\mathrm{H}_{\mathrm{E}}$ observed in Saudi native chicken breeds in the current study were similar to or slightly lower than those reported by Zhang et al [7] in Chinese native breeds.

All studied breeds showed no inbreeding within breed (negative inbreeding coefficient $\left[\mathrm{F}_{\mathrm{IS}}\right]$ ). The mean $\mathrm{F}_{\mathrm{IS}}$ for Saudi native chicken breeds was lower than zero $(-0.07)$. These values were similar to that reported by Tadano et al [36] for 12 commercial chicken lines ( 0.000 to 0.141 ) based on 40 microsatellite loci, while it was lower than that reported by Kaya and Yildiz [26] and Ding et al [37] for Turkish and Chinese native chicken breeds, respectively. To decrease $\mathrm{F}_{\mathrm{IS}}$, full- or half-sib mating should be avoided to prevent inbreeding depression. Among breeds, the mean $\mathrm{F}_{\mathrm{IS}}$ values varied from -0.01 for naked neck black breed to -0.10 in both normally feathered brown and black barred. The mean $\mathrm{F}_{\mathrm{ST}}$ value of 0.02 indicates that approximately $2 \%$ of the total genetic variation is caused by breed differences, whereas the remaining amount (98\%)was due to differences among individuals within breeds. With respect to HWE, black chicken breeds (either normal or naked neck) and normal brown breed exhibited a deviation from HardyWeinberg equilibrium (dHWE). Out of all $120 \mathrm{HWE}$ tests in 6 breeds tested, dHWE at the 5\% level recorded $12.9 \%$. Contrary with our results, Ding et al [37] reported that all breeds showed statistically significant deviation from the HWE at many loci.

\section{Genetic distance among Saudi native chicken breeds} Molecular information of genetic diversity is playing an important role in conservation of chicken resources. Genetic distance based on Nei's unbiased values is presented in Table 6. The high genetic diversity in Saudi native chicken breeds is consistent with great phenotypic variation among them. The greatest genetic distance was found between gray and brown breeds (0.246). The smallest figure was recorded between the naked neck and normally feathered black populations (0.107). Both normally feathered and naked neck Black breeds (0.107) were most closely related to each other than that of normally feathered and frizzle brown populations (0.139). According 
Table 6. Genetic distance matrix among Saudi native chicken breeds

\begin{tabular}{lcccccc}
\hline Breed & BL-Nana & BR-ff & BL-nana & BR-ff & BB & G \\
\hline BL-Nana & - & & & & & \\
BR-ff & 0.157 & - & & & & \\
BL-nana & 0.107 & 0.122 & - & & & \\
BR-ff & 0.176 & 0.139 & 0.149 & - & & \\
BB & 0.112 & 0.159 & 0.126 & 0.200 & - & \\
G & 0.159 & 0.210 & 0.168 & 0.246 & 0.234 & - \\
\hline
\end{tabular}

BL-Nana, heterozygous naked neck black breed; BR-Ff, heterozygous frizzled brown breed; BL-nana, normally feathered black breed; BR-nana, normally feathered brown breed; BB, black-barred breed; G, gray breed.

to many reports, local chickens from Africa and Asia are characterized by extensive phenotypic variations within and between different populations [35,38-46]. Similarly, high microsatellite diversity was reported within chicken strains from Iran, China, Turkey, Korea, Sudan, Southeast African countries $[25,26,35,47,48]$. Uncontrolling breeding programs and traditional management systems may be contribute to higher variations within and between these populations. Consistent with our findings, Osman et al [49] and Tadano et al [36] reported that the use of 20 microsatellite markers and approximately 24 birds per breed might be adequate to obtain accurate results of genetic diversity in Japanese chicken breeds.

The unrooted NJ tree derived from the Nei's standard genetic distance of six Saudi native chicken breeds is given in Figure 1. It could be observed that three main clusters were clearly recognized. Frizzled brown breed and normally feathered brown breed located in one cluster, while naked neck black breed with black-barred breed located in the second cluster. Finally, normal black breed and the gray breed were located in the third cluster. The black and gray breeds were placed to the cluster whose distance is far from naked neck black and black barred breeds. Additionally, naked neck black breed (BL-Nana) grouped with the black barred one (BB).

\section{CONCLUSION}

In conclusion, determining genetic biodiversity between chicken breeds is considered as an initial step of strategic plan for genetic characterization and conservation of Saudi native chickens. Evaluation of genetic diversity among Saudi native chicken breeds based on 20 microsatellite markers studied in the current study was efficient and gained reliable results.

\section{CONFLICT OF INTEREST}

We certify that there is no conflict of interest with any financial organization regarding the material discussed in the manuscript.

\section{ACKNOWLEDGMENTS}

This work was supported by Qassim University, Al-Qassim, KSA.

\section{REFERENCES}

1. FAO. Molecular genetic characterization of animal genetic resources. FAO Animal Production and Health Guidelines; No. 9. Rome, Italy: FAO; 2011.

2. Fulton JE, Delany ME. Poultry genetic resources-operation rescue needed. Science 2003;300:1667-8.

3. Minga U, Msoffe P, Gwakisa P. Biodiversity in disease resistance and in pathogens within rural chickens. In: Proceedings of the 22nd World's Poultry Congress. June 8-12, Istanbul, Turkey; 2004.

4. Fathi MM, Al-Homidan I, Motawei MI, Abou-Emera OK, El-Zarei MF. Evaluation of genetic diversity of Saudi native chicken populations using microsatellite markers. Poult Sci 2017;96:530-6.

5. Qu L, Li X, Xu G, et al. Evaluation of genetic diversity in Chinese indigenous chicken breeds using microsatellite markers. Sci China C Life Sci 2006;49:332-41.

6. Fathi MM, Galal A, El-Safty SA, Mahrous M. Naked neck and frizzle genes for improving chickens raised under high ambient temperature: I. Growth performance and egg production. World's Poult Sci J 2013;69:813-32.

7. Zhang X, Leung FC, Chan DKO, Yang G, Wu C. Genetic diversity of Chinese native chicken breeds based on protein polymorphism, randomly amplified polymorphic DNA, and microsatellite polymorphism. Poult Sci 2002;81:1463-72.

8. Bodzsar N, Eding H, Revay T, Hidas A, Weigend S. Genetic diversity of Hungarian indigenous chicken breeds based on microsatellite markers. Anim Genet 2009;40:516-23.

9. Tadano R, Nagasaka N, Goto N, Rikimaru K, Tsudzuki M. Genetic characterization and conservation priorities of chicken lines. Poult Sci 2013;92:2860-5.

10.Sartore S, Sacchi P, Soglia D, et al. Genetic variability of two Italian indigenous chicken breeds inferred from microsatellite marker analysis. Br Poult Sci 2016;57:435-43.

11.Hillel J, Granevitze Z, Twito T, et al. Molecular markers for the assessment of chicken biodiversity. World's Poult Sci J 2007; 63:33-45.

12. Granevitze Z, Hillel J, Chen GH, et al. Genetic diversity within chicken populations from different continents and management histories. Anim Genet 2007;38:576-83.

13. Rajkumar U, Gupta BR, Ahmed N, Venktramaiah A, Reddy AR. Genetic variation and genetic diversity in chicken populations using microsatellite assay. Indian J Anim Sci 2007;77: 1194-8.

14. Abebe AS, Mikko S, Johansson AM. Genetic diversity of five local Swedish chicken breeds detected by microsatellite markers. 
PLoS One 2015;10:e0120580.

15. Yacoub H, Fathi MM. Phylogenetic analysis using d-loop marker of mtDNA in Saudi native chicken breeds. Mitochondrial DNA 2013;24:538-51.

16. Ahmed AS, Alhudaib KA, Soliman AM. Genetic diversity of Hajar1 and Hajar2 local Saudi chicken lines using mitochondrial DNA D-loop markers. S Afr J Anim Sci 2016;46:409-18.

17. Belkhir K, Borsa P, Chikhi L, Raufaste N, Bonhomme F. GENETIX 4.05, logiciel sous Windows TM pour la génétique des populations. Laboratoire Génome, Populations, Interactions, CNRS UMR 5000. Montpellier, France: Université de Montpellier II; 2004.

18. Rousset F. Genepop'007: A complete reimplementation of the Genepop software for Windows and Linux. Mol Ecol Resour 2008;8:103-6.

19. Goudet J. FSTAT version 1.2. A computer program to calculate F-statistics. J Hered 1995;86:485-6.

20. Nei M. Genetic distance between populations. Am Nat 1972; 106:283-92.

21. Cavalli-Sforza L, Edwards A. Phylogenetic analysis. Models and estimation procedures. Am J Human Genet 1967;19:23357.

22. Takezaki N, Nei M, Tamura K. POPTREE2: software for constructing population trees from allele frequency data and computing other population statistics with Windows interface. Mol Biol Evol 2010;27:747-52.

23. Berthouly C, Bed-Hom B, Tixier-Boichard M, et al. Using molecular markers and multivariate methods to study the genetic diversity of local European and Asian chicken breeds. Anim Genet 2008;39:121-9.

24. Pham MH, Berthouly-Salazar C, Tran XH, et al. Genetic diversity of Vietnamese domestic chicken populations as decisionmaking support for conservation strategies. Anim Genet 2013; 44:509-21.

25. Shahbazi S, Mirhosseini, SZ, Romanov MN. Genetic diversity in five Iranian native chicken populations estimated by microsatellite markers. Biochem Genet 2007;45:63-75.

26. Kaya M, Yildiz MA. Genetic diversity among Turkish native chickens, Denizli and Gerze, estimated by microsatellite markers. Biochem Genet 2008;46:480-91.

27.Emara MG, Kim H, Zhu J, et al. Genetic diversity at the major histocompatibility complex (B) and microsatellite loci in three commercial broiler pure lines. Poult Sci 2002;81:1609-17.

28. Cheng HH, Levin I, Vallejo RL, et al. Development of a genetic map of the chicken with markers of high utility. Poult Sci 1995; 74:1855-74.

29. Nasiri BMT, Hamidi Z, Tavakoli S. The investigation of genetic variation at microsatellite loci in Mazandaran native chickens. Int J Poult Sci 2007;6:675-8.

30. Nasiri BMT, Shokri F, Khanian SE, Tavakoli S. Study on polymorphism of Island native chicken population using microsatellites markers. Int J Poult Sci 2007;6:835-7.
31. Weir BS, Cockerham CC. Estimating F-statistics forth analysis of populationstructure. Evolution 1984;38:1358-70.

32. Hillel J, Groenen MA, Tixier-Boichard M, et al. Biodiversity of 52 chicken populations assessed by microsatellite typing of DNA pools. Genet Sel Evol 2003;35:533-57.

33. Wei L, Chen B, Li X, Liu S, Wang J. Genetic diversity of four protected indigenous chicken breeds in China using microsatellite markers. S Afr J Anim Sci 2013;43:464-72.

34. Ramadan S, Kayang BB, Inoue E, et al. Evaluation of genetic diversity and conservation priorities for Egyptian chickens. Open J Anim Sci 2012;2:183-90.

35. Muchadeyi FC, Eding H, Wollny CB, et al. Absence of population substructuring in Zimbabwe chicken ecotypes inferred using microsatellite analysis. Anim Genet 2007;38:332-9.

36. Tadano R, Nishibori M, Nagasaka N, Tsudzuki M. Assessing genetic diversity and population structure for commercial chicken lines based on forty microsatellite analyses. Poult Sci 2007;86:2301-8.

37. Ding FX, Zhang GX, Wang JY, et al. Genetic diversity of a Chinese native chicken breed, Bian chicken, based on twenty-nine microsatellite markers. Asian-Australas J Anim Sci 2010;23:154-61.

38. Msoffe PL, Minga UM, Olsen JE, et al. Phenotypes including immunocompetence in scavenging local chicken ecotypes in Tanzania. Trop Anim Health Prod 2001;33:341-54.

39. Mwacharo JM, Nomura K, Hanada H, et al. Genetic relationships among Kenyan and other East African indigenous chickens. Anim Genet 2007;38:485-90.

40. Chen G, Bao W, Shu J, et al. Assessment of population structure and genetic diversity of 15 chinese indigenous chicken breeds using microsatellite markers. Asian-Australas J Anim Sci 2008; 21:331-9.

41. Rajkumar U, Gupta BR, Reddy AR. Genomic heterogeneity of chicken populations of India. Asian-Australas J Anim Sci 2008;21:1710-20.

42. Cuc N, Simianer H, Eding $H$, et al. Assessing genetic diversity of Vietnamese local chicken breeds using microsatellites. Anim Genet 2010;41:545-7.

43. Dana N, Dessie T, van der Waaij LH, van Arendonk JAM. Morphological features of indigenous chicken populations of Ethiopia. Anim Genet Resour 2010;46:11-23.

44. Mtileni BJ, Muchadeyi FC, Maiwashe A, et al. Genetic diversity and conservation of South African indigenouschicken populations. J Anim Breed Genet 2011;128:209-18.

45.Leroy G, Kayang BB, Youssao IAK, et al. Gene diversity, agroecological structure and introgression patterns among village chicken populations across North, West and Central Africa. BMC Genet 2012;13:34.

46. Lyimo CM, Weigend A, Janßen-Tapken U, et al. Assessing the genetic diversity of five Tanzanian chicken ecotypes using molecular tools. S Afr J Anim Sci 2013;43:499-510.

47. Bao W, Chen G, Li B, et al. Analysis of genetic diversity and phylogenetic relationships among red jungle fowls and Chinese 
domestic fowls. Sci China Ser C Life Sci 2008;51:560-8.

48. El-Tanany M, Distl O. Genetic diversity and genealogical origins of domestic chicken. World's Poult Sci J 2010;66:715-26.

49. Osman SAM, Sekino M, Nishihata A, et al. The genetic vari- ability and relationships of Japanese and Foreign chickens assessed by microsatellite DNA profiling. Asian-Australas J Anim Sci 2006;19:1369-78. 